\title{
Description of a new species of Cylloepus Erichson from southeastern Brazil (Coleoptera, Elmidae)
}

\author{
Maria Inês Silva Passos ${ }^{1,3} \&$ Márcio Felix $x^{2,3}$
}

\begin{abstract}
${ }^{1}$ Departamento de Zoologia, Instituto de Biologia, Universidade Federal do Rio de Janeiro. Caixa Postal 68044, 21944-970 Rio de Janeiro-RJ, Brazil. E-mail: mines@biologia.ufrj.br

${ }^{2}$ Departamento de Entomologia, Museu Nacional, Universidade Federal do Rio de Janeiro. Quinta da Boa Vista, São Cristóvão, 20940-040 Rio de Janeiro-RJ, Brazil. E-mail: mfelix@acd.ufrj.br

${ }^{3}$ Programa de Pós-graduação em Zoologia, Museu Nacional, Universidade Federal do Rio de Janeiro.
\end{abstract}

\begin{abstract}
Cylloepus dorvillei sp. nov. is described and illustrated from a first order stream at the Atlantic Forest in Rio de Janeiro State, Brazil. Taxonomic and habitat notes on the new species are presented.

KEYwords. Atlantic Forest; morphology; Neotropics; riffle beetle; taxonomy.

Resumo. Descrição de uma nova espécie de Cylloepus Erichson do sudeste do Brasil (Coleoptera, Elmidae). Cylloepus dorvillei sp. nov. é descrita e ilustrada com base em espécimes coletados em um rio de primeira ordem na Mata Atlântica do Estado do Rio de Janeiro, Brasil. Notas sobre a taxonomia e o hábitat da nova espécie são apresentadas.

Palavras-chave. Besouro de correnteza; Mata Atlântica; morfologia; Região Neotropical; taxonomia.
\end{abstract}

The primarily Neotropical genus Cylloepus Erichson, 1847 have been listed from Arizona, USA, to southern Brazil and Argentina. This genus is currently known from 51 species (Grouvelle 1889; Hinton 1934, 1936, 1937a, b, 1940a, 1945a, b, 1951; SANDERSON 1953; Brown 1981). Nineteen species were recorded from Brazil (states of Minas Gerais, Rio de Janeiro, and Santa Catarina) (Hinton 1937b, 1945a). Cylloepus can be distinguished from the remaining New World elmid genera by the combination of the following features: (1) gula not distinctly narrower than submentum or mentum (WHITE \& BRIGHAM 1996); (2) prosternal process moderately narrow (HINTON 1940b); and (3) hypomera usually without tomentum (HinTON 1940b).

In this paper, a new species of Cylloepus from a first order stream at the Atlantic forest in Rio de Janeiro State, southeastern Brazil, is described and illustrated. Taxonomic and habitat notes on the new species are included.

The type series herein designated is deposited in Departamento de Zoologia, Universidade Federal do Rio de Janeiro, Rio de Janeiro, RJ, Brazil (DZRJ). In quotations of label data, a reversed virgule $(\backslash)$ separates lines on a label. Morphological terminology follows mainly HinTON (1940b). The specimens are pinned or preserved in $80 \%$ ethyl alcohol. The dissected genital structures are stored in microvials with glycerin.

\section{Cylloepus dorvillei sp. nov.}

(Figs. 1-7)

Holotype, male. Length $4.0 \mathrm{~mm}$, greatest width $1.4 \mathrm{~mm}$. Body (Figs. 1-2) subparallel; surface with rounded to ellipsoid tubercles. Head and thorax: head (Figs. 1-2) with inconspicuous distinct impressions; anterior portion of vertex and dorsal portion to eyes with few moderately short setae; posterodorsal portion with sparse, very short setae; posteroventral portion to eyes tomentose. Eyes with posterior margin rounded, slightly elongate posteriorly. Antennae filiform. Clypeus with anterior margin truncate; lateral angles broadly rounded. Labrum with anterior margin truncate; lateral angles broadly rounded; anterolateral portions with some moderately long setae. Genae with ventral portion bearing some long setae. Pronotum (Fig. 1) approximately as wide as long; anterior width less than posterior width; anterior margin medially truncate, lateral portions concave; anterior angles produced, triangular, acute; lateral margins somewhat convex; posterolateral angles slightly produced, subtriangular, acute; disc convex; sublateral carinae prominent, rounded, approximately fusiform; median carinae similar to sublateral ones, posteriorly convergent, with anterior portion wide. Elytra (Fig. 1) approximately parallelsided, two and a half times as long as prothorax; anterior margin convex; outer margin crenate; apex moderately produced, surface without striae or carinae; striae narrow, with numerous punctures except on apical portion; punctures wide, deep, rounded to ellipsoid; intervals narrow, approximately twice as broad as striae; some intervals with rounded punctures; each elytron with two sublateral carinae extending posteriorly from humerus along approximately three-fourths of elytral length, the innermost at sixth interval; third interval carinate on anterior third. Scutellum (Fig. 1) flat, slightly longer than wide; anterior margin truncate; apex convex. Prosternum (Fig. 2) with anterior process broadly subrectangular; anterior margin of process slightly concave; anterolateral angles rounded; prosternal process broad, extending slightly beyond anterior coxae; posterior margin of process with median convex projection; proepisternum with blunt, short process on anterior 

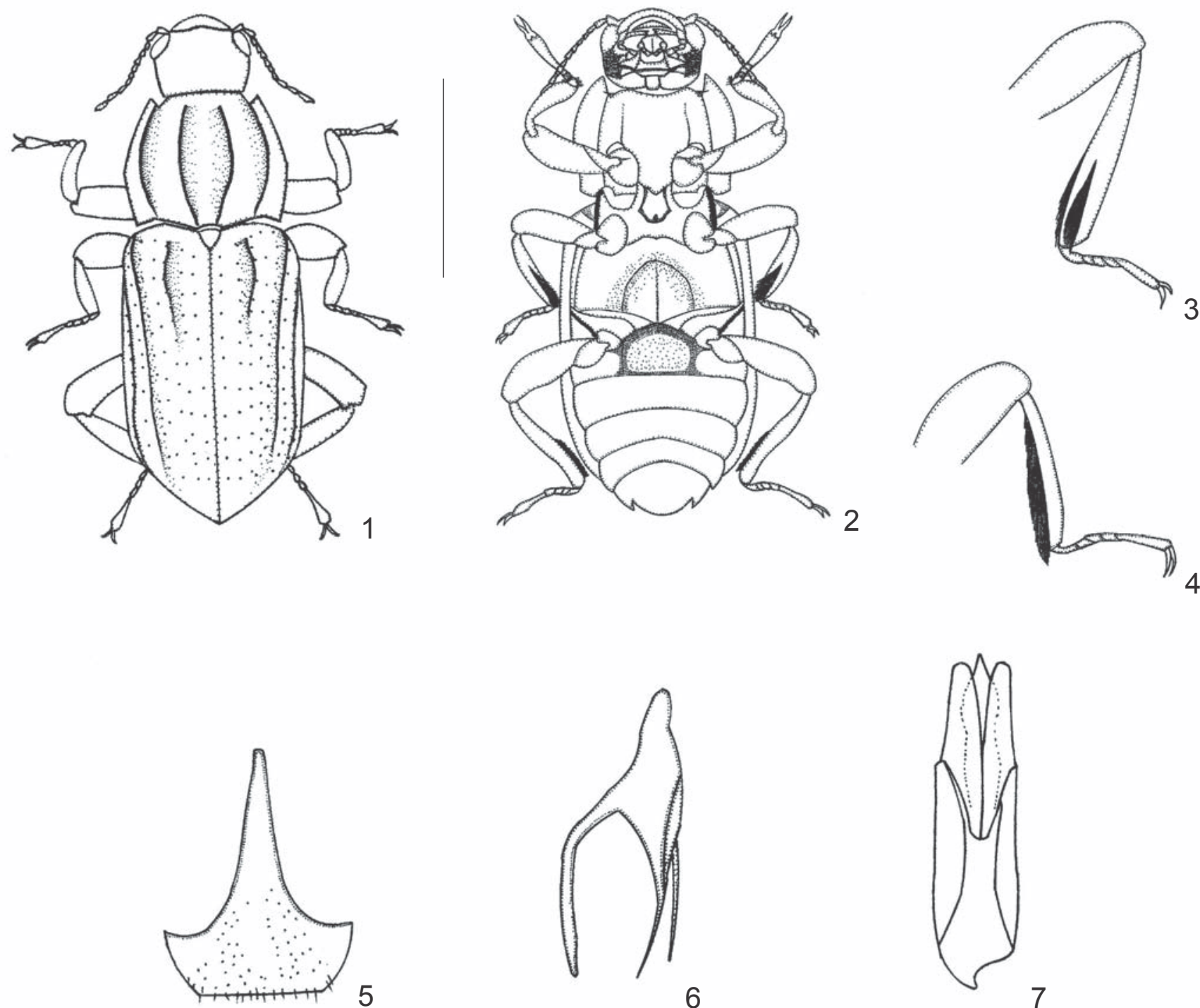

Figs. 1-7. Cylloepus dorvillei sp. nov. (holotype): 1, dorsal habitus; 2, ventral habitus; $\mathbf{3}$, detail of left median tibia showing anterior and ventral fringes of tomentum, anterior view; $\mathbf{4}$, detail of right median tibia showing ventral fringe of tomentum, posterior view; 5, abdominal sternum 6 , ventral view; 6, spicule; 7 , genitalia, ventral view. Scale bar $=1.5 \mathrm{~mm}$.

portion. Metasternum (Fig. 2) depressed on anterior portion, with longitudinal median sulcus; posterior portion broadly depressed. Median tibiae (Figs. 3-4) each with two fringes of tomentum, anterior one short, ventral one long. Posterior tibiae (Fig. 2) each with a single ventrolateral fringe of tomentum. Remaining morphological characteristics of head and thorax as in the generic redescription of HinTON (1940b). Abdomen: Sternum 1 (Fig. 2) strongly depressed medially; depression continuous with that of the metasternum, lateral margins slightly carinate. Sternum 5 (Fig. 2) with posterior margin broadly convex. Sternum 6 (Fig. 5) with posterior margin truncate; surface with sparse setae, more closer on apical portion. Spicule (Fig. 6) with anterior portion broad. Genitalia: parameres (Fig. 7) elongate; apical portion stout; apex rounded. Median lobe (Fig. 7) longer than parameres, elongate, slightly constricted medially; apical portion produced-digitiform. Color: cuticle reddish-brown; antennae, mouth-parts, and tarsi yellowish-brown.

Intraspecific variation. Size range $(n=11)$ : length 4.0-4.4 $\mathrm{mm}$, greatest width 1.4-1.6 mm. The types do not present significant color or morphological variation.

Holotype: male, "Rio de Janeiro, RJ, Floresta da Tijuca, Rio da Fazenda \L. F. Dorvillé leg. $\backslash 25 / \mathrm{V} / 1995 \backslash$ Amostra II 5" (DZRJ). Paratypes: 1 female, same data as holotype; 1 male, idem except "Amostra X 6"; 1 female, idem except "Amostra X 7"; 1 male, idem except "Amostra X 10"; 1 male and 1 female, idem except "13/VIII/ 1994\Amostra I 1"; 1 male, idem except "13/VIII/1994\ Amostra I 8"; 1 female, idem except "20/XI/1994\Amostra IV 6"; 1 female, idem except "19/II/1995 Amostra VII 9"; 1 male, idem as preceding except “Amostra VII 10" (DZRJ). 
Habitat notes. The members of the type series were collected in a first order stream (Rio da Fazenda) at the National Park of Tijuca (22 $\left.2^{\circ} 55^{\prime} \mathrm{S}-23^{\circ} 00^{\prime} \mathrm{S}, 043^{\circ} 11^{\prime} \mathrm{W}-043^{\circ} 19^{\prime} \mathrm{W}\right)$, an Atlantic Forest reserve in southeastern Brazil. The collection point was located at 400 meters of altitude. The specimens were mainly found at leaf litter caught in riffles.

Remarks. Cylloepus dorvillei sp. nov. is very similar to $C$. brasiliensis Grouvelle, 1888, C. sharpi Grouvelle, 1888, and C. reitteri Grouvelle, 1888. These species share two sublateral and two median carinae on pronotum and one inner and two outer carinae on each elytron (GrouvelLe 1889; HinTON 1937b). The inner carina is absent in C. reitteri (HinTon 1937b). The shape and position of the carinae are variable among the cited species.

Cylloepus dorvillei can be distinguished from the three species cited above by the combination of the following features: pronotum (Fig. 1) with (1) sublateral carinae prominent and rounded, approximately fusiform, (2) median carinae similar to sublateral ones, posteriorly convergent, with anterior portion wide; elytra (Fig. 1) each with (3) two sublateral carinae extending posteriorly from humerus along approximately threefourths of elytral length, the innermost at sixth interval, (4) third interval carinate on anterior third; median tibiae (Figs. 34) each with (5) two fringes of tomentum, anterior one short, ventral one long.

The pronotum of C. brasiliensis has rounded sublateral carinae and rounded convergent median carinae (GROUVELLE 1889). Each elytron of this species presents outer carinae evanescent toward apex and inner carina extending along the anterior fourth of the elytral length. Cylloepus sharpi has a pronotum with sublateral and median carinae depressed and parallel-sided (GrouvelLe 1889). Its elytra have inner carina slight and extending along the anterior third of elytral length. The pronotum of $C$. reitteri presents sublateral and median carinae rounded (GROUVELLE 1889; HinTON 1937b); the median carinae are anteriorly and posteriorly connected. The inner carina is absent on the elytra of this species. Cylloepus brasiliensis, C. sharpi, and C. reitteri have only one fringe of tomentum on each median tibia (HINTON 1937b), while in the new species there are two fringes.

Cylloepus dorvillei keys to couplet 8 in Hinton's (1945a) key. This couplet establishes the distinction between $C$. carinulus Hinton, 1945 and the couplet 9, which separates $C$. nicon Hinton, 1945 from C. nelo Hinton, 1945. The new species has a pronotum with two complete sublateral carinae and with a distinct median longitudinal impression, while in C. carinulus those carinae are distinct only very near anterior margin and that impression is absent. Each elytron of $C$. carinulus does not present inner sublateral carina and the outer one is prominent only near apex. Moreover, its third interval is only feebly convex. Cylloepus dorvillei has one short prominent carina at third interval and two long sublateral carinae. The two species included in the couplet 9 present each elytron carinate at third interval along about anterior $7 / 10$ of elytral length, while in the new species this carina extends only on anterior third. Besides, C. nicon and C. nelo have different types of punctures on the pronotal disc, while $C$. dorvillei has only tubercles on this surface.

Etymology. The species epithet, dorvillei, is in honor of Prof. Luís Fernando M. Dorvillé (Universidade do Estado do Rio de Janeiro, Rio de Janeiro, Brazil).

Acknowledgement. We are grateful to L. F. M. Dorvillé for collecting the specimens of the new species. The manuscript benefited from the useful comments of G. Mejdalani, H. P. Brown, J. L. Nessimian, K. Hobson, N. Ferreira-Jr, and two anonymous reviewers. Fellowships from Coordenação de Aperfeiçoamento de Pessoal de Nível Superior (CAPES, Brazil) to both authors are acknowledged.

\section{REFERENCES}

Brown, H. P. 1981. A distributional survey of the world genera of aquatic dryopoid beetles (Coleoptera: Dryopidae, Elmidae, and Psephenidae sens. lat.). Pan-Pacific Entomologist 57: 133-148.

Grouvelle, M. A. 1889. Nouvelles espèces d'Helmides. Annales de la Société Entomologique de France 8: 393-412.

Hinton, H. E. 1934. Miscellaneous studies in the Helminae (Dryopidae, Coleoptera). Revista de Entomologia 4: 192-199.

Hinton, H. E. 1936. Synonymical and other notes on the Dryopidae (Coleoptera). Entomologists' Monthly Magazine 72: 54-58.

Hinton, H. E. 1937a. Notes on some Brazilian Potamophilinae and Elmidae (Coleoptera, Dryopidae). Entomologists' Monthly Magazine 73: 95-100.

Hinton, H. E. 1937b. New species of Cylloepus from Brazil (Coleoptera, Dryopidae). The Entomologist 70: 279-284.

Hinton, H. E. 1940a. A synopsis of the Bolivian species of Cylloepus Er. (Coleoptera, Elmidae). Annals and Magazine of Natural History 6: 393-409.

Hinton, H. E. 1940b. A monographic revision of the Mexican water beetles of the family Elmidae. Novitates Zoologicae 42: 19-396.

Hinton, H. E. 1945a. A synopsis of the Brazilian species of Cylloepus Er. (Coleoptera, Elmidae). Annals and Magazine of Natural History 12: 43-67.

Hinton, H. E. 1945b. A synopsis of the Peruvian species of Cylloepus Er. (Coleoptera, Elmidae). Annals and Magazine of Natural History 12: 713-733.

Hinton, H. E. 1951. A new Cylloepus from Argentina (Coleoptera, Elmidae). Annals and Magazine of Natural History 4: 820 823.

SAnderson, M. W. 1953. New species and a new genus of New World Elmidae with supplemental keys. The Coleopterists Bulletin 7: 33-40.

White, D. S. \& W. U. Brigham. 1996. Aquatic Coleoptera, p. 399-473. In: R. W. Merritt \& K. W. Cummins (eds.). Aquatic Insects of North America. Dubuque, Kendall/Hunt, 862 p. 